\title{
Global chemical and isotope heterogeneity in the early Earth's mantle revealed by Pilbara komatiites and basalts
}

\author{
IGOR S PUCHTEL ${ }^{1}$, MARY F. HORAN ${ }^{2}$, RICHARD J. \\ WALKER $^{3}$, EUAN NISBET ${ }^{4}$ AND MAREK LOCMELIS ${ }^{5}$ \\ ${ }^{1}$ Department of Geology, University of Maryland \\ ${ }^{2}$ Carnegie Institution for Science \\ ${ }^{3}$ University of Maryland \\ ${ }^{4}$ Royal Holloway, University of London \\ ${ }^{5}$ Missouri University of Science and Technology \\ Presenting Author: ipuchtel@umd.edu
}

Although the heterogeneous nature of the Earth's mantle in terms of lithophile and siderophile element isotope and abundance systematics is now well established, the origin and longevity of these heterogeneities remain poorly understood. This is particularly so for the early Archean mantle, where the variations are largest, yet the available rock record is limited. In this study, we report ${ }^{143} \mathrm{Nd} /{ }^{144} \mathrm{Nd},{ }^{176} \mathrm{Hf} /{ }^{177} \mathrm{Hf},{ }^{187} \mathrm{Os} /{ }^{188} \mathrm{Os}$, and ${ }^{182} \mathrm{~W} /{ }^{184} \mathrm{~W}$ isotope and lithophile and highly siderophile element abundance data for komatiites and basalts from the $\sim 3.5 \mathrm{Ga}$ Coonterunah, 3.3 Ga Kelly, and 3.2 Ga Ruth Well and Regal systems of the Pilbara Craton in Western Australia. The Sm-Nd, $\mathrm{Lu}-\mathrm{Hf}$, and Re-Os isotope data yield isochrons consistent with the accepted emplacement ages of the komatiite-basalt lavas. Their mantle sources evolved with long-term variably suprachondritic $\mathrm{Sm} / \mathrm{Nd}$ and $\mathrm{Lu} / \mathrm{Hf}$ ratios (model ${ }^{147} \mathrm{Sm} /{ }^{144} \mathrm{Nd}=$ $0.200 \pm 4$ to $0.215 \pm 4,{ }^{176} \mathrm{Lu} /{ }^{177} \mathrm{Hf}=0.0358 \pm 2$ to $0.0391 \pm 3$ versus 0.1967 and 0.0336 in the BSE, respectively). The near-coupled ${ }^{143} \mathrm{Nd}-{ }^{176} \mathrm{Hf}$ isotope systematics argue for only limited, if any, involvement of magma ocean processes in the magma genesis. The significant variations in the initial $\gamma^{187}$ Os values from $+1.1 \pm 0.2$ to $-2.5 \pm 0.4$ indicate that the early Archean mantle sources evolved with both moderately supra- to sub-chondritic time-integrated Re/Os. The calculated total HSE abundances in the komatiite mantle sources range from $\sim 30$ to $\sim 70 \%$ of those in estimates for the present-day BSE, thus, indicating a $>2 \times$ increase from 3.5 to 3.2 Ga All four komatiite-basalt systems studied exhibit positive ${ }^{182} \mathrm{~W}$ anomalies between $+12 \pm 5$ and $+9 \pm 5$ ppm.

The combined ${ }^{182} \mathrm{~W}-\mathrm{HSE}$ systematics of the Pilbara komatiitebasalt systems are inversely correlated and, along with the lack of evidence for the involvement of early magma ocean processes, are most consistent with grainy late accretion of large differentiated planetesimals that would be expected to have created significant coupled long-lived HSE abundance and W isotope heterogeneities in the pre-late accretion mantle. Variabledegree upper mantle partial melting and melt extraction, following late accretion, would account for the observed significant variations in the time-integrated $\mathrm{Re} / \mathrm{Os}, \mathrm{Sm} / \mathrm{Nd}$, and $\mathrm{Lu} / \mathrm{Hf}$ ratios in the early Archean mantle domains. None of these domains were similar in composition to the projections for the BSE. 